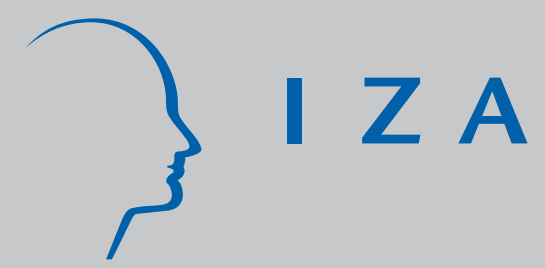

IZA DP No. 7911

Minimum Wage: Does It Improve Welfare in Thailand?

Ximena Del Carpio

Julián Messina

Anna Sanz-de-Galdeano

January 2014

Forschungsinstitut zur Zukunft der Arbeit Institute for the Study of Labor 


\title{
Minimum Wage: Does It Improve Welfare in Thailand?
}

\author{
Ximena Del Carpio
}

World Bank

\author{
Julián Messina \\ World Bank and IZA
}

\author{
Anna Sanz-de-Galdeano \\ CRES-UPF, MOVE, World Bank and IZA
}

\author{
Discussion Paper No. 7911 \\ January 2014
}

\author{
IZA \\ P.O. Box 7240 \\ 53072 Bonn \\ Germany \\ Phone: +49-228-3894-0 \\ Fax: +49-228-3894-180 \\ E-mail: iza@iza.org
}

Any opinions expressed here are those of the author(s) and not those of IZA. Research published in this series may include views on policy, but the institute itself takes no institutional policy positions. The IZA research network is committed to the IZA Guiding Principles of Research Integrity.

The Institute for the Study of Labor (IZA) in Bonn is a local and virtual international research center and a place of communication between science, politics and business. IZA is an independent nonprofit organization supported by Deutsche Post Foundation. The center is associated with the University of Bonn and offers a stimulating research environment through its international network, workshops and conferences, data service, project support, research visits and doctoral program. IZA engages in (i) original and internationally competitive research in all fields of labor economics, (ii) development of policy concepts, and (iii) dissemination of research results and concepts to the interested public.

IZA Discussion Papers often represent preliminary work and are circulated to encourage discussion. Citation of such a paper should account for its provisional character. A revised version may be available directly from the author. 


\section{ABSTRACT}

\section{Minimum Wage: Does It Improve Welfare in Thailand? ${ }^{1}$}

We study the causal impact of the minimum wage on employment and welfare in Thailand using a difference-in-difference approach that relies on exogenous policy variation in minimum wages across provinces. We find that minimum-wage increases have small disemployment effects on female, elderly, and less-educated workers and large positive effects on the wages of prime-age male workers. As such, increases in the minimum wage are associated with increases in household consumption per capita in general, but the consumption increase is greatest among those households around the median of the distribution. In fact, rises in the minimum wage increased inequality in consumption per capita within the bottom half of the distribution.

JEL Classification: J31, D31

Keywords: minimum wage, household consumption, poverty, employment, uncovered sector

Corresponding author:

Anna Sanz-de-Galdeano

Departament d'Economia i d'Història Econòmica

Office B3-194, Building B, Campus Bellaterra

Universitat Autònoma de Barcelona

Bellaterra 08193, Barcelona

Spain

E-mail: anna.sanzdegaldeano@gmail.com

\footnotetext{
${ }^{1}$ We would like to thank Kirida Bhaopichitr, John Giles, Lars Sondergaard, and seminar participants at the World Bank in Thailand for helpful comments. The authors would like to thank the National Economic and Social Development Board of Thailand and World Bank colleagues for providing critical data inputs. This research was sponsored by the World Bank under contract 7800772 and the Development Research Funds. The opinions expressed in this article do not necessarily reflect the views of the World Bank. The authors declare that they have no relevant or material financial interests that relate to the research described in this paper. Financial support from the Government of Catalonia (contract 2009SGR189 and the XREPP) and the Government of Spain (through the ECO2011-28822 Grant) is gratefully acknowledged.
} 


\section{Introduction}

The minimum wage constitutes a key labor market policy instrument in both developed and developing countries. In developing countries, where tax bases are limited and hence resources for other labor market policies (e.g., active labor market policies) are scarce, minimum wages are used even more often with an objective of lifting the fortunes of low-skilled workers and poor individuals. But do minimum-wage increases actually help them escape poverty?

A large literature examining the impact of the minimum wage on labor market outcomes has been extensively surveyed by Card and Krueger (1997), Flinn (2010), and Neumark and Wascher (2010). Although there is broad consensus on the positive impact of the minimum wage on average wages, its effects on employment are still heatedly debated. Some authors argue that the standard textbook analysis of the minimum wage, which predicts disemployment effects, is at odds with the evidence, which shows few signs of increased joblessness after minimum-wage increases in developed countries (Card and Krueger 1997; Dickens, Machin. and Manning 1999). Instead, they interpret the empirical evidence as supportive of monopsonistic behavior in the labor market, whereby minimum-wage raises help to compress the wage distribution at the bottom without reducing employment. Other authors, including Neumark and Wascher (2010), argue that the literature tilts in favor of those studies that find a negative employment effect.

The study of possible disemployment effects of the minimum wage in developing countries is complicated by those countries' large informal sectors and frequent noncompliance with labor policy. ${ }^{2}$ Considerable evidence gathered in Latin America yields nonuniform conclusions (as surveyed by Cunningham 2007). Large negative effects of the minimum wage increases on formal employment are found in Honduras (Gindling and Terrell 2009), while effects on employment are small in Costa Rica (Gindling and Terrell 2007) and Colombia (Maloney and Núñez 2003) and not statistically significant in Mexico (Bell 1997) and Brazil (Lemos 2009). Much less is known about other developing regions such as Southeast Asia, with the notable exception there of Indonesia, for which various studies have found small negative employment effects after minimum-wage spikes (Rama 2001; Alatas and Cameron 2008; Del Carpio, Nguyen, and Wang 2011). However, despite decreases in formal employment, average employment rates did not change in either Indonesia (Comolla and Mello 2011) or Vietnam (Nguyen 2010). More recently, Magruder (2013) has argued that previous empirical studies evaluating the role of the minimum wage in Indonesia may have been contaminated by methodological (namely, endogeneity) biases, thus making the results less valid. He uses a difference-in-special-differences estimator, which arguably reduces the likelihood of endogeneity biases, and

\footnotetext{
2 The paper uses informal and uncovered sectors interchangeably, to denote sectors in which workers are either not legally subject to the minimum wage law, or being legally subject the law is not enforced.
} 
finds that minimum-wage increases boosted employment and wages in the economic sectors covered by the policy.

The academic focus on how minimum-wage increases affect employment contrasts with policy makers' emphasis on how minimum-wage legislation would affect income distribution. ${ }^{3}$ In fact, the literature studying the impact of the minimum wage on poverty or on income or consumption inequality is much scarcer than the literature studying its impact on employment, ${ }^{4}$ and most of it focuses on developed economies (Terrell and Almeida, 2008). Interestingly, most studies find that disemployment effects tend to concentrate among the low-skilled, thereby casting doubt on the effectiveness of using minimum-wage policy as a lever to reduce poverty. Moreover, minimum-wage workers are often not the most disadvantaged in developing countries; on the contrary, formal minimum-wage workers are protected by labor policy, while workers in the informal sector likely earn below the minimum wage. Thus, the minimum wage may not be an effective tool to reduce inequality or poverty in this context.

This paper conducts a fairly comprehensive examination of the impact of changes to the minimumwage level in Thailand from 2001 through $2011 .{ }^{5}$ It focuses on the heterogeneity of the estimated effect of minimum-wage changes on a wide range of labor-related and social outcomes, including wages, employment, hours of work, poverty and household consumption. The analysis distinguishes between different skill groups (unskilled, medium-skilled, and high-skilled) and demographic characteristics such as age and gender. The detailed analysis offers insights into the impact of the minimum wage on welfare, and enables an examination of the mechanisms through which it operates.

Thailand constitutes an excellent case study to analyze the impact of the minimum wage on labor market outcomes because of the way the country implements and administers its policy and because of the nature of its dual labor market (formal and informal). During the period of analysis, the minimum wage in Thailand was set by province, introducing a great variability of minimum wages across the country and over time. These various provincial minimum wages were set following a complex, two-tiered system that involved near-continnual negotiations between tripartite committees at the provincial and national levels.

As the next section shows, such a complex negotiation process introduced a great deal of arbitrariness in the minimum wages set. Decision making responded more to imbalances in bargaining power

\footnotetext{
3 The popular press is full of these examples. U.S. President Barack Obama, in his 2013 State of the Union address, said, "Tonight, let's declare that in the wealthiest nation on Earth, no one who works full-time should have to live in poverty, and raise the federal minimum wage to $\$ 9.00$ an hour” (New York Times 2013)

${ }^{4}$ A simple online search in Google Scholar for articles with the words "minimum wage" and "employment" in the title yielded 273 hits. Replacing "employment" with "poverty” or "inequality” yielded 39 and 43 hits, respectively.

${ }^{5}$ In 2012, Thailand raised its minimum wage substantially (by 35-70 percent, depending on the starting point of each province); however, this study focuses on yearly "moderate" changes.
} 
between employers and employees and to the central government's desire to maintain provincial status quos than to a careful process of planning and targeting. As a result, variation of the minimum wage over time and within provinces was, to a large extent, exogenous to changes in the local labor market. Hence, we use a difference-in-difference strategy to identify the causal impact of minimum-wage changes on labor market and household outcomes - a strategy that is not likely to suffer from the common endogeneity biases found in many previous studies. This paper also contributes to the literature by shedding light on the impact of minimum-wage increases on labor and social outcomes in a middle-income country where large segments of the workforce are employed in the informal (uncovered) economy, where labor law is not binding. Indeed, as in most developing countries, the vast majority of Thai households have at least one member employed in the informal economy. ${ }^{6}$

The remainder of the paper is organized as follows. The next section discusses the institutional features of the Thai minimum-wage system and describes the recent evolution of minimum wages in Thailand. Section 3 introduces the main datasets used for the analyses and describes the characteristics of minimum-wage workers. Section 4 discusses the methodology used to estimate the impact of the minimum wage on labor market outcomes and presents the main results, organized around three interrelated questions: How has the minimum wage affected wages on average and across distinct labor market demographic groups? How has the minimum wage affected formal and informal employment (especially among potentially vulnerable groups such as youth, elder workers, female workers, and low-skilled workers)? Has the minimum wage been an effective tool for tackling poverty and reducing consumption inequality? Section 5 concludes with a summary of the paper's findings and a discussion of their implications.

\section{Thai Minimum Wages: Institutional Background and Recent Evolution}

The minimum wage has been a key component in the development of Thai labor policy over the past four decades. $^{7}$ In 1972, the first minimum-wage legislation passed in Thailand, ${ }^{8}$ and the Ministry of Interior appointed a tripartite National Wage Committee (NWC) of government, employer, and employee representatives to recommend labor policy to the government and fix the minimum wage, which was defined

${ }^{6}$ In 2011, about 63 percent of country's working-age population (15-60 years old) worked in the informal economy, (NSO 2011).

7 This section draws from three main sources: (a) Peetz (1996), a comprehensive analysis of Thailand's minimum-wagesetting system (up to the promulgation of the Labor Protection Act of 1998). This study was sponsored by the International Labour Organization after the Thai government requested its technical assistance; (b) Paitoonpong, Akkarakul, and Sukaruji (2005), a study that updates knowledge on the minimum-wage-setting system following the passage of the Labor Protection Act; and (c) our own conversations with Ministry of Labor officials and members of the National Wage Committee.

8 The legislation, Revolutionary Party Decree No. 103, was promulgated on March 16, 1972. 
as "a wage rate which an employee deserves and is sufficient for an employee's living." The first minimum wage was set at 12 baht per day in April 1973 in Bangkok and three surrounding provinces (Samut Prakan, Nonthaburi, and Pathum Thani). The criteria reportedly used in wage negotiations were the cost of living; the rate of inflation as reflected by the consumer price index (CPI); and, since 1990, economic growth. ${ }^{9}$ After 1973, minimum wages continued to be set by geographic zone, and, by 1998, three different minimum wages covered all 76 Thai provinces. ${ }^{10}$

The 1997-98 Asian financial crisis led to a reform of Thailand's labor policy, and the Labor Protection Act of 1998 (LPA 2541) transformed the previous minimum-wage-setting system into a two-tiered system intended to differentiate minimum-wage levels by province and industry. The main objective of having province-specific levels was to take into account provincial differences in the cost of living and other socioeconomic conditions. The new system fully adopted the provincial differentiation, but the industry-level differentiation was not implemented, largely because it was too complex to administer.

One of the LPA 2541's primary mandates was the creation of a new minimum-wage-setting machinery, which included three key institutions: the NWC, the Provincial Subcommittees on Minimum Wages (PSMWs), and the Subcommittee on Technical Affairs and Review (STAR). Despite the introduction of the new system in 1998, no adjustments to minimum-wage levels were made until 2001. In 2008, a new reform (the Labor Protection Act of 2008 [LPA 2551]) further detailed the criteria established for wage adjustments, but in practice made no major changes to the wage-setting process. Finally, in 2011, the newly elected government announced a unified nationwide policy that, by January 2013, had set minimum wages at 300 baht per day (about 9.5 US\$ at the time) in all provinces. This drastic increase, however, does not affect our results because it became effective after 2011.

During the period under study, the rounds of negotiations to review the minimum-wage level were typically triggered by trade union demands, NWC or PSMW recommendations, or government order. It is the duty of the PSMWs (tripartite subcommittees composed of government, employer, and employee representatives) to recommend minimum-wage adjustments at the provincial level to the NWC, which then sends these recommendations to STAR for technical review. After STAR submits its review, the NWC issues a final recommendation at the central level, which the Ministry of Labor (the final deciding authority) then announces in the Royal Gazette. Although the Ministry of Labor may ask the NWC to revise its

\footnotetext{
${ }^{9}$ In particular, the formula proposed was the following: rate of economic growth divided by two plus the inflation rate (Peetz 1996). Note, however, that these criteria were used as a reference, and the final outcome was determined by negotiations between the government, employer, and employee representatives on the NWC.

${ }^{10}$ In 1998, before the passage of the Labor Protection Act, minimum wages were 162 baht per day in Bangkok, Nakhon Pathom, Nonthaburi, Pathum Thani, Samut Sakhon, Samut Prakan, and Phuket; 140 baht per day in Chon Buri, Chiang Mai, Nakhon Ratchasima, Phangnga, Ranong, and Saraburi; and 130 baht per day in the remaining provinces.
} 
recommendations, it rarely interferes with the review process beyond its influence on the different committees through its official representatives.

The frequency of minimum-wage adjustments is generally not fixed by law in East Asian countries, but they usually revise them annually. Thailand was no exception to this pattern during the 2000s: minimumwage adjustments were generally decided by the NWC after the review process in November and became effective on January 1 of the following year. However, there were two adjustments in some years (2005 and 2008) and none in 2009. As a result of these adjustments, Thailand had 28 different minimum wages by the end of 2010 — ranging from 151 baht per day (about US\$4.80 of 2010) in Phrae, Phayao, Mae Hong Son, and Phichit (in the North region) to 206 baht per day (about US\$6.50) in Bangkok and Samut Prakan (in the Central region). As for coverage, Thai minimum wages apply to all full-time private employees regardless of nationality, although they do not apply to government employees, employees in households, employees in the agricultural sector, and part-time or student employees.

In 1998, the LPA 2541 (article 87) also stipulated three main groups of indicators on which to base minimum-wage adjustments: cost of living, employers' capacity to pay, and economic conditions. ${ }^{11}$ On paper, the reliance on these criteria would introduce some degree of endogeneity in the determination of the minimum wage, a problem that is fairly common in most of the related literature. In practice, however, minimum-wage negotiations often differed widely from the text of the legislation for various reasons. First, the precise weight assigned to each criterion by the members of the committees was not preestablished. During our conversations, stakeholders suggested that cost-of-living considerations and regional gross domestic product (GDP) per capita were given priority, possibly because of data availability, but negotiations took place rather informally, and the criteria used may well have varied across provinces and over time.

Second, the low rate of unionization and the large share of informal employment severely limit Thai workers' capacity to coordinate efforts, which results in a review process dominated by the employer representatives and the government. The virtual absence of unions at the provincial level complicates the selection and appointment of employee representatives for the PSMWs, which often lacks transparency. The appointed employee representatives are sometimes not even known among the workers (Paitoonpong, Akkarakul, and Sukaruji 2005). During interviews with union and employer representatives at the NWC, it was often told to us that in some PSMWs, employer and employee representatives work in the same firm, the former having personally handpicked the latter. Even if employee representatives are present, they are often not prepared enough to contribute to the technical discussion. Hence, it is not surprising that the growth in

\footnotetext{
11 The differences between the set of criteria established in the LPA 2541 (1998) and the LPA 2551 (2008) were minimal. The latter further detailed the three broad criteria established by the former, and it added the following ones: inflation rate, subsistence standard, production costs, goods and service price, labor productivity, and GDP.
} 
nominal minimum wages during the 2000s (figure 1) was not enough to keep up with inflation, and real minimum wages fell steadily in the four regions of the country as a result (figure 2$).^{12}$

Finally, the unavailability of suitable data, especially but not exclusively at the provincial level, turns the minimum-wage review process into an excessively political one, further reducing the probability that its outcome is tightly linked to the actual evolution of the economic indicators outlined in the LPA 2541. Although the NWC gives the PSMWs written suggestions on data sources for the indicators to be considered for minimum-wage adjustments, it neither provides them with the actual data nor establishes a national minimum-wage guideline.

In sum, the wage negotiations carried out by the PSMWs are unlikely to have responded to supply and demand conditions in a systematic manner.

Figure 1. Growth of the Nominal Minimum Wage in Thailand, by Region, 1998-2010
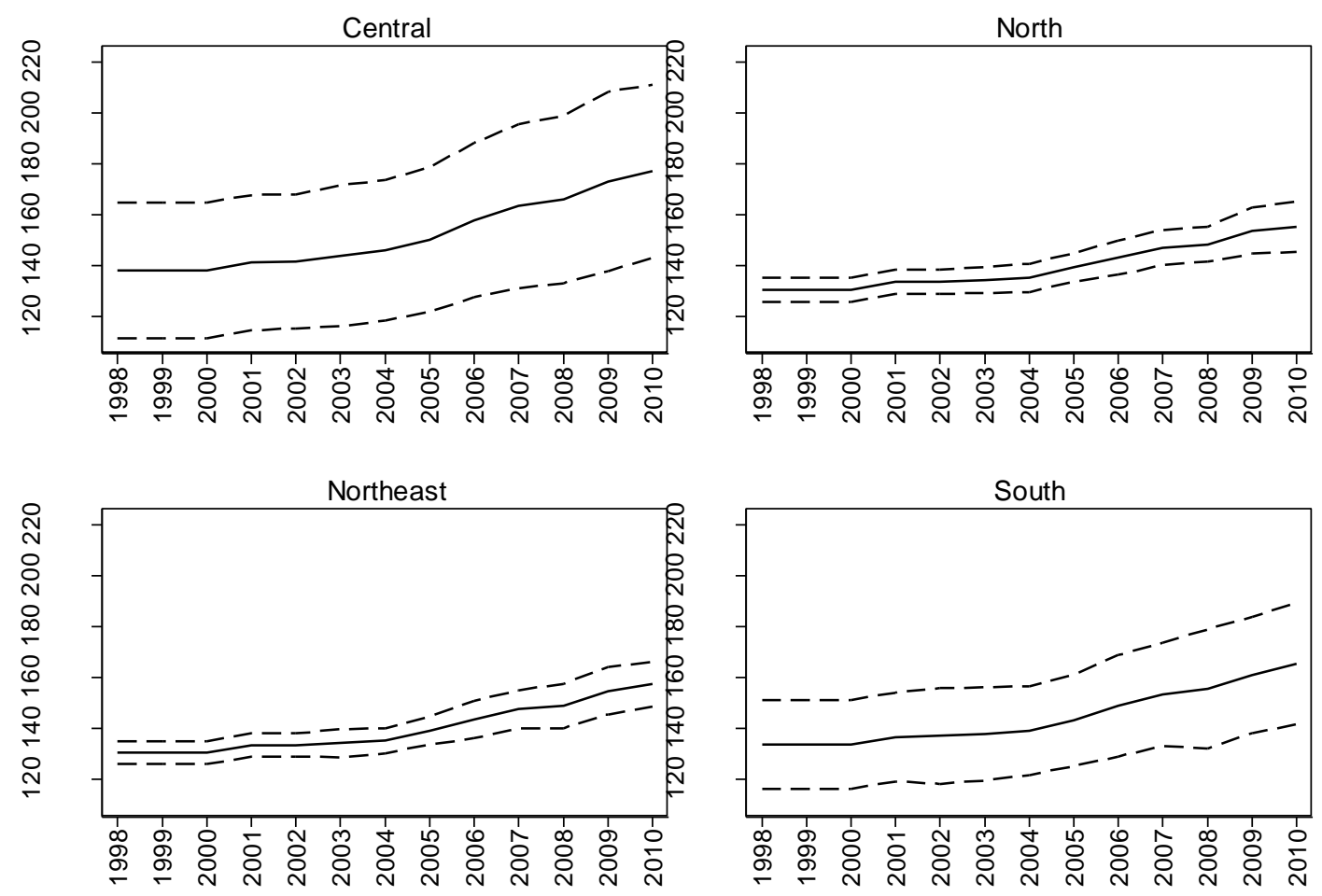

Note: The solid line depicts the average minimum wage (measured in current bahts) per region, and the dashed lines represent one standard deviation above and below it.

\footnotetext{
${ }^{12}$ The interviews were held during a World Bank field mission that took place on February 13-17, 2012. All interviews were conducted in confidentiality, and the names of interviewees are withheld by mutual agreement.
} 
Figure 2. Growth of the Real Minimum Wage in Thailand, by Region, 1998-2010
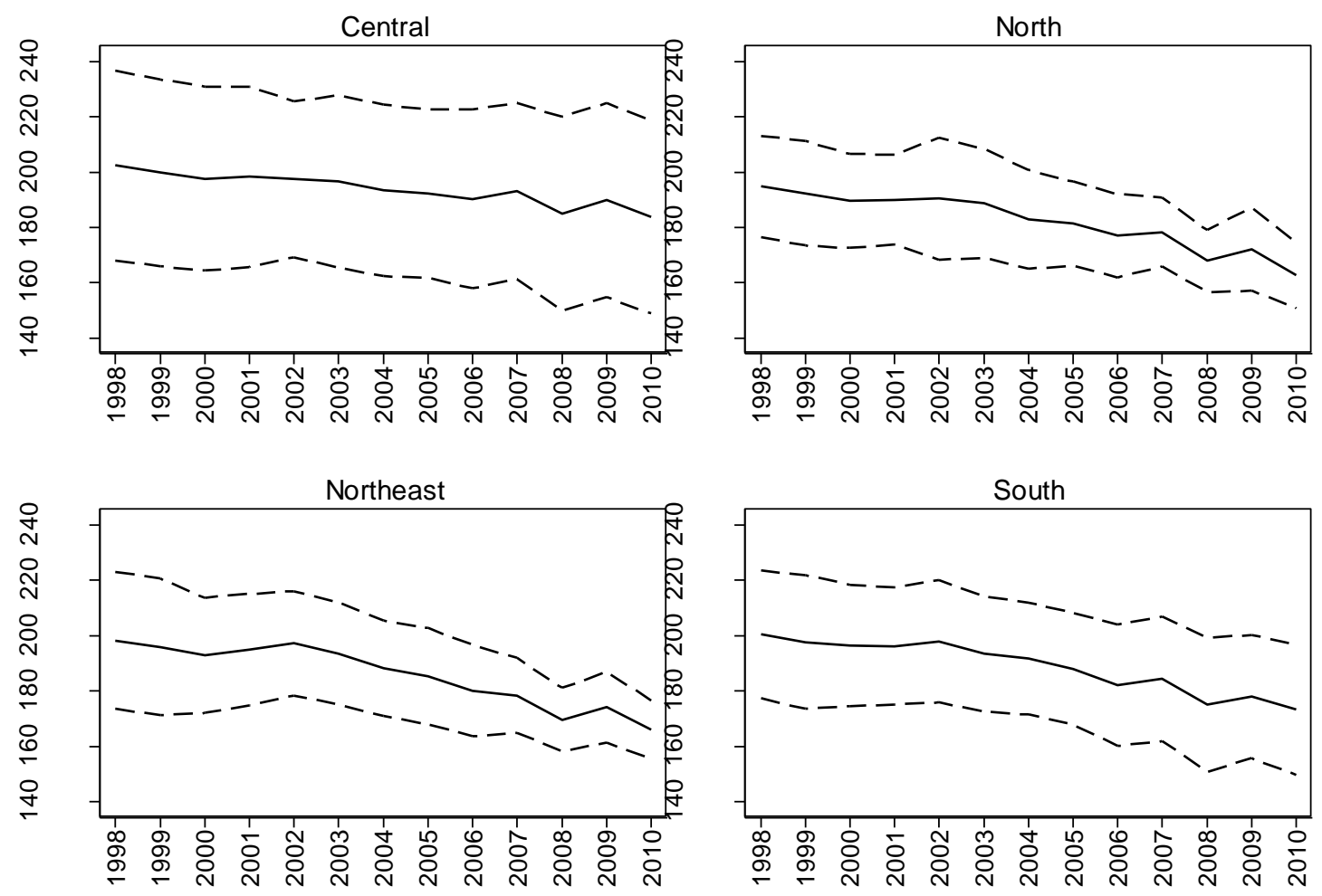

Note: The solid line depicts the average real minimum wage (measured in constant Baht) per region, and the dashed lines represent one standard deviation above and below it. Minimum wages are deflated using the provincial CPI.

More importantly, another source of exogenous variation affects minimum-wage outcomes from the negotiations. NWC members told us that they often considered another criterion (not stipulated by the LPA 2541) before reaching a final recommendation: the extent of cross-provincial disparities. In particular, the NWC generally tried to avoid exacerbating cross-provincial differences in the minimum wage (which indeed remained fairly stable along our period of analysis, as the standard deviations across provinces in figure 1 indicate) or, at the minimum, attempted to maintain the status quo in terms of provincial rankings (within regions). To this purpose, the NWC used to compensate provinces that had lagged behind within the region in terms of their previous (nominal) minimum-wage adjustment, while it set relatively smaller minimum-wage increases in provinces that had previously fared better than the regional average.

We present evidence supportive of these trend reversals within regions in table 1, which displays estimates of the determinants of two alternative measures of relative within-region minimum-wage adjustments: The first one (columns 1-3) is an indicator variable that takes the value one if the province's percentage increase in the minimum wage is above the regional average; otherwise, it takes the value zero. 
The second measure (columns 4-6) is the provincial ranking (within-region) in terms of the minimum-wage percentage increases received. We regress these two indicators on their lagged values, seeking evidence of trend reversals. In the first specification (columns 1 and 4), we include region dummies on top of the lag of the dependent variable. Next (columns 2 and 5), we control for provincial inflation and the growth rate of real per capita provincial GDP (that is, the main indicators on which data are systematically collected that should be considered in fixing minimum wages according to article 87 of the LPA 2541). Finally (columns 3 and 6), we include the lag of the latter two variables as additional controls.

Our results from column 1 show that the likelihood of getting a minimum-wage increase above the regional average is significantly smaller in provinces where the previous minimum-wage raise was above the regional average. Along these lines, we also find that the provincial ranking (within the region) in terms of minimum-wage percentage increases (column 4) was significantly higher the lower the province had ranked at the previous minimum-wage change date. It is also worth highlighting that the impact of inflation and GDP growth on the growth of the minimum wage is far from significant at standard levels of testing, and the results are virtually unchanged when adding these variables (and their lags) as further controls (columns 2, 3, 5 , and 6).

Additionally, we estimated an analogous model to investigate the determinants of the percentage increase in minimum wages at the province level and reached similar conclusions: current increases in minimum wages were significantly smaller the higher the previous increases had been, and they were not significantly affected by inflation or GDP growth, the inclusion of which did not significantly change the other relevant coefficient estimates. ${ }^{13}$

This process of ex-post compensation of the provincial minimum wages that was put in place to guarantee a regional balance introduced exogenous variation in the changes over time of the minimum wage within provinces. Importantly, these changes appear to be driven by institutional factors rather than by supply and demand in the local labor markets. To be sure, wages, employment, and minimum wages are jointly determined at the aggregate level, and the entrenched minimum-wage differences across provinces through 2011 reflected different levels of development. Hence, the identification in the analyses below will rely on time variation of the minimum-wage within provinces, abstracting from permanent differences across provinces and common macroeconomic shocks by introducing year, month, and province dummy variables into the regression. We argue that, in light of the evidence on trend reversals presented here, and given the great deal of arbitrariness in the complex, two-tiered, tripartite system of minimum-wage negotiations, the remaining variation within-province in minimum wages is exogenous to local labor market conditions, and therefore exogenous to employment, poverty, and wage setting at the provincial level.

\footnotetext{
13 These results are available upon request from the authors.
} 
Table 1. Determinants of Relative (Within-Region) Minimum-Wage Changes in Thailand

\begin{tabular}{|c|c|c|c|c|c|c|}
\hline & \multicolumn{3}{|c|}{$\begin{array}{l}\text { Minimum-wage growth higher than } \\
\text { regional average }\end{array}$} & \multicolumn{3}{|c|}{ Minimum-wage growth ranking } \\
\hline & $(1)$ & (2) & (3) & (4) & $(5)$ & (6) \\
\hline $\begin{array}{l}\text { Lag minimum-wage growth } \\
\text { higher than regional } \\
\text { average }\end{array}$ & $\begin{array}{l}-0.1524^{* * *} \\
(0.03207)\end{array}$ & $\begin{array}{l}-0.1528^{* * *} \\
(0.03219)\end{array}$ & $\begin{array}{c}-0.1605^{* * *} \\
(0.03203)\end{array}$ & - & - & - \\
\hline $\begin{array}{l}\text { Lag minimum-wage growth } \\
\text { ranking }\end{array}$ & - & - & - & $\begin{array}{l}-0.1419^{* *} \\
(0.04266)\end{array}$ & $\begin{array}{l}-0.1420^{* *} \\
(0.04259)\end{array}$ & $\begin{array}{l}-0.1435^{* *} \\
(0.04321)\end{array}$ \\
\hline Inflation & No & $\begin{array}{l}-0.005152 \\
(0.006319)\end{array}$ & $\begin{array}{l}-0.005488 \\
(0.006345)\end{array}$ & No & $\begin{array}{c}0.05351 \\
(0.07489)\end{array}$ & $\begin{array}{c}0.05407 \\
(0.07601)\end{array}$ \\
\hline $\begin{array}{l}\text { Real per capita GDP } \\
\text { growth }\end{array}$ & No & $\begin{array}{l}-0.1209 \\
(0.3613)\end{array}$ & $\begin{array}{l}-0.1147 \\
(0.3650)\end{array}$ & No & $\begin{array}{c}1.2801 \\
(4.5917)\end{array}$ & $\begin{array}{c}1.3568 \\
(4.6583)\end{array}$ \\
\hline Lag inflation & No & No & $\begin{array}{r}-0.007570 \\
(0.006520)\end{array}$ & No & No & $\begin{array}{l}-0.02867 \\
(0.07611)\end{array}$ \\
\hline $\begin{array}{l}\text { Lag real per capita GDP } \\
\text { growth }\end{array}$ & No & No & $\begin{array}{c}0.1571 \\
(0.2845)\end{array}$ & No & No & $\begin{array}{c}1.5090 \\
(3.2748)\end{array}$ \\
\hline Region dummies & Yes & Yes & Yes & Yes & Yes & Yes \\
\hline$N$ & 684 & 684 & 684 & 684 & 684 & 684 \\
\hline
\end{tabular}

Note: In columns (1)-(3), the dependent variable takes the value one if the province's percentage change in the minimum wage is above the regional average, and the value zero otherwise. In columns (4)-(6), the dependent variable ranks each province's minimum-wage percentage increase within the region. Reported estimates are probit average partial effects in columns (1)-(3) and OLS coefficient estimates in columns (4)-(6). Clustered standard errors are displayed in parentheses. The analysis considers Thailand's 76 provinces in nine minimum-wage change dates (January 2003, January 2004, January 2005, August 2005, January 2006, January 2007, January 2008, June 2008, and January 2010), which yields a sample of 684 observations.

${ }^{*} p<0.05 \quad{ }^{* *} p<0.01 \quad{ }^{* * *} p<0.001$

One final issue that requires consideration is compliance. Although the LPA 2541 and the LPA 2551 establish penalties that include fines and in some cases imprisonment, the resources allocated to monitoring are limited in Thailand, and recent data from the Department of Labor Protection and Welfare indicate that employers are seldom penalized over minimum-wage breaches (Leckcivilize 2013). Weak enforcement may in turn reduce compliance and hence hamper the potential effectiveness of minimum-wage legislation. ${ }^{14}$ In the next section, we describe our main data sources and empirically assess the extent of noncompliance with Thai minimum wages in the covered sector.

${ }^{14}$ See, for instance, ILO (2010). 


\section{Data and Descriptive Evidence}

\subsection{Data sources}

This paper relies on two main data sources: the Labor Force Survey (LFS), on which we base our individuallevel analyses of labor market outcomes, and the Household Socio-Economic Survey (SES), which we use to study the impact of the minimum wage on household consumption and poverty.

The National Statistical Office of Thailand (NSO) undertakes the LFS to collect data on the economic activities of the population, including detailed information on employment and unemployment as well as on characteristics of the labor force and economically inactive individuals. The LFS relies on a twostage stratified sampling design (Thailand's 76 provinces constituted the strata), ${ }^{15}$ and it covers the civilian noninstitutional population living in private households and special households (which include group households or quarters within a factory compound). LFS data, which are collected monthly and released quarterly, also include information on relevant socioeconomic characteristics such as age, gender, marital status, and education.

To study the impact of the minimum wage on the Thai labor market, we focus on the period 19982010 and adapt our sample selection criteria to the specific outcome under study: the wages and hours ${ }^{16}$ worked by 15 - to 60 -year-old full-time employees covered by minimum wages. ${ }^{17}$ Two samples — those of all working-age (15-60) individuals and of working-age private sector workers-serve as the bases for our analyses of the probability of employment and the probability of working in the covered or uncovered sector, respectively. Regarding wage measurement, since Thai minimum wages are set per day, the wage variable we use is also a daily rate, ${ }^{18}$ which we deflate when necessary by provincial CPI.

Our analyses of poverty and household consumption rely on the SES, a stratified two-stage sampling survey that the NSO typically carries out every two years. The goal of the SES is to collect socioeconomic information on Thai households, such as consumption, characteristics of household members and housing, ownership of selected durable goods, and so forth. We use data from all years available within our period of analysis: that is, 2000, 2002, 2004, 2006, 2007, 2008, 2009, and 2010.

\footnotetext{
15 Primary and secondary sample units are blocks (for municipal areas) or villages (for non-municipal areas) and households, respectively.

16 Wages and hours worked are considered only for the worker's main job.

17 The retirement age is 60 in Thailand.

${ }^{18}$ For employees paid by the month, monthly wages were converted to a daily rate by dividing by 30 .
} 


\subsection{Who pays and who receives the minimum wage? How binding are Thai minimum wages?}

Data on labor inspections conducted by the Department of Labor Protection and Welfare reveal that, on average, 12-13 percent of establishments were inspected every year during 2006-10, but more than 94 percent of the establishments violating any labor law received only a warning, and less than 0.3 percent were actually penalized or prosecuted (Leckcivilize 2013). Therefore, noncompliance with Thai minimum wages may be relevant even for formal employees, and the following questions are warranted: Are Thai covered employees actually paid at or above the minimum wage? Who are and who aren't?

To answer these questions, we depart from the sample of workers covered by minimum-wage legislation to characterize those who are paid above and below the minimum wage. Because few workers earn exactly the minimum wage, we define minimum-wage workers (labeled as "At the minimum" in table 2) as those for whom the difference between the actual daily wage received and the daily minimum wage in the province where they work does not exceed (in absolute terms) 5 percent. The other two categories, "Below" and "Above", identify workers whose wage is more than 5 percent lower and higher than the minimum wage, respectively.

Table 2 presents summary statistics for these three groups and uncovers a significant degree of noncompliance: around 20 percent of Thai employees are paid less than the minimum wage, according to our characterization - a remarkable feature considering that these summary statistics are based on the sample of workers who, in principle, are covered by minimum wages as stipulated by the legislation. This result is broadly consistent with other compliance indicators based on alternative data sources. ${ }^{19}$

Regarding worker characteristics, younger workers (aged 15-24) are more likely than prime-aged workers (aged 25-49) to be below or at the minimum wage. Because female wages are lower, compliance also varies by gender: 25.9 percent of females earn less than the minimum, against only 17.8 percent of males. As for firm size, large firms are more likely to pay at or above minimum wages, while small firms are more prone to noncompliance. For example, 41.8 percent of individuals working in firms with 1 to 5 employees earn below the minimum wage, against only 5.3 percent of their counterparts working in firms with more than 200 employees. The incidence of and noncompliance with minimum wages also decreases as education increases and is more prevalent among blue-collar workers. ${ }^{20}$

\footnotetext{
${ }^{19}$ See, for instance, Paitoonpong, Akkarakul, and Sukaruji (2005); DLPW (2002); and Peetz (1996).

${ }^{20}$ Chandoevwit (2010) reports similar patterns of noncompliance across workers and firms based on LFS data.
} 
Table 2. Summary Statistics on Private Sector Wages Relative to Minimum Wage in Thailand

\begin{tabular}{|c|c|c|c|}
\hline & Below the minimum & At the minimum & Above the minimum \\
\hline \multicolumn{4}{|l|}{ By worker characteristic } \\
\hline Female & 25.88 & 23.85 & 50.28 \\
\hline Male & 17.79 & 15.73 & 66.48 \\
\hline Less than elementary education & 35.15 & 18.83 & 46.02 \\
\hline Elementary education & 27.62 & 24.48 & 47.91 \\
\hline Lower secondary education & 21.15 & 26.25 & 52.59 \\
\hline Upper secondary education & 12.85 & 20.41 & 66.74 \\
\hline Tertiary education & 2.80 & 4.36 & 92.84 \\
\hline Age 15-24 & 29.72 & 27.11 & 43.18 \\
\hline Age 25-44 & 17.54 & 17.84 & 64.62 \\
\hline Age $45-60$ & 24.72 & 13.93 & 61.35 \\
\hline \multicolumn{4}{|l|}{ By occupation } \\
\hline Legislators, senior officials & 1.00 & 0.94 & 98.06 \\
\hline Technicians and associates & 4.13 & 6.94 & 88.93 \\
\hline Clerks & 7.23 & 11.33 & 81.44 \\
\hline Service workers, shop, and related & 31.45 & 15.50 & 53.05 \\
\hline Skilled agriculture and fisheries & 56.41 & 17.97 & 25.62 \\
\hline Craft and related trades & 13.40 & 17.13 & 69.47 \\
\hline Plant and machine operators & 11.25 & 32.10 & 56.65 \\
\hline Elementary occupation & 41.89 & 24.02 & 34.10 \\
\hline \multicolumn{4}{|l|}{ By industry } \\
\hline Agriculture, hunting, forestry, fisheries & 59.65 & 15.81 & 24.54 \\
\hline Manufacturing, electricity, gas, and water & 11.49 & 30.09 & 58.43 \\
\hline Construction & 12.94 & 13.04 & 74.02 \\
\hline Wholesale and retail trade & 20.62 & 13.93 & 65.45 \\
\hline Hotels and restaurants & 37.67 & 15.22 & 47.11 \\
\hline Transport, storage, and related & 14.93 & 8.44 & 76.62 \\
\hline Financial inter. and real estate & 8.57 & 10.53 & 80.90 \\
\hline Education & 11.13 & 7.41 & 81.46 \\
\hline Health, social, and household services & 39.03 & 13.58 & 47.39 \\
\hline \multicolumn{4}{|l|}{ By firm size } \\
\hline 1-4 employees & 41.84 & 14.66 & 43.49 \\
\hline 5-9 employees & 32.01 & 14.56 & 53.43 \\
\hline 10-19 employees & 25.02 & 16.53 & 58.45 \\
\hline 20-199 employees & 14.09 & 18.62 & 67.29 \\
\hline $200+$ employees & 5.31 & 28.00 & 66.69 \\
\hline Total & 21.30 & 19.26 & 59.44 \\
\hline
\end{tabular}

Note: Sample drawn from 1998-2010 LFS data on working-age (15-60 years old) full-time private employees paid by the day or by the month. Workers "at the minimum" wage are defined as those actual daily wage received is within 5 percent above or below the minimum wage in their province. For workers "below the minimum" and "above the minimum," wages are more than 5 percent lower or higher than the minimum wage, respectively. 
An alternative way of assessing noncompliance and how binding minimum wages are is to look for spikes in the wage distribution at or around the minimum wage. Because Thai minimum wages during the period analyzed differed across provinces and over time, we define a new variable that measures the difference between the wage of each employee and the minimum wage in the province where he or she works, and we then pool all Thai covered employees by year. Figure 3 displays kernel density estimates of the distribution of the difference between actual daily wages and the minimum wage for each year of our sample period. Two main features are worth noting: First, there is a visible spike at or very close to zero, which is the mode of the wage distribution in all years. Hence, minimum wages are clearly binding. Second, as table 2 revealed, there is also a significant fraction of workers who are paid below the minimum wage in the covered sector.

In sum, our evidence indicates that, although compliance is far from perfect, Thai minimum wages are clearly binding. Importantly, the extent of noncompliance appears to vary substantially by socioeconomic characteristics. Hence, the impact of minimum-wage legislation is likely to vary across groups of employees, a feature we take into account in our subsequent analyses.

Figure 3. Kernel Density Functions of the Difference between Actual Wages and Minimum Wage in Thailand, 2001-10
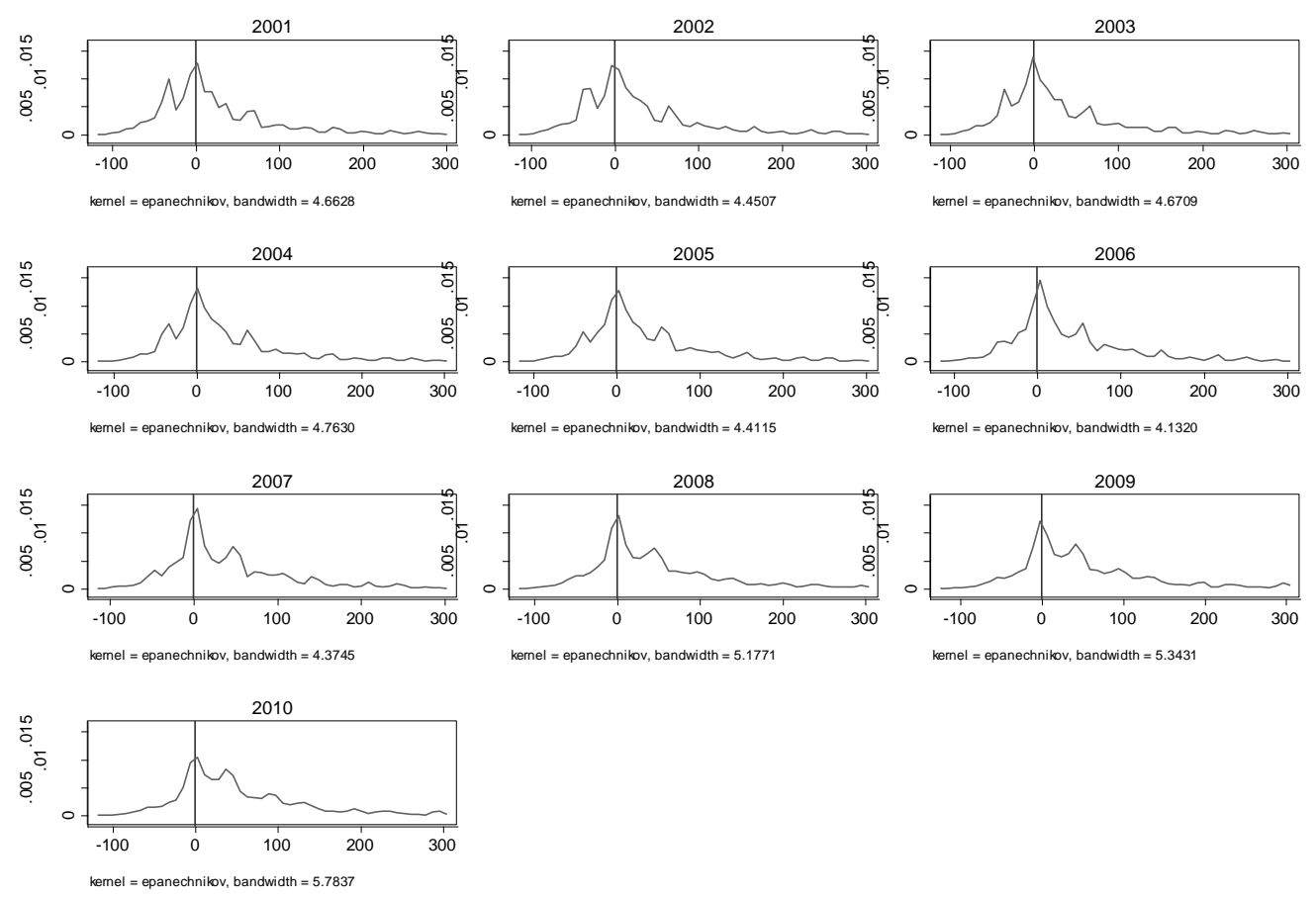

Note: Kernel densities display the log of real daily wages of full-time (35+ hours per week) private salaried workers. The sample includes employees who are paid by the day as well as employees who are paid by the month. 


\section{Estimation and Results}

\subsection{Empirical model and identification}

We estimate the impact of the minimum wage on various outcomes by relying on a difference-in-differences identification strategy. In particular, we estimate equations of the following form:

$$
y_{i t}=\beta_{0}+\ln M W_{p t} \beta_{1}+X_{i t} \alpha+\delta_{t}+\gamma_{p}+\varepsilon_{i t}
$$

where $y_{i t}$ denotes the outcome of interest (we start by looking at individual real daily wages and then we move to employment, informality, and poverty) and $\ln M W_{p t}$ the log of the minimum wage; $i$ stands for individuals (in the labor market outcomes analyses) and for households (in the poverty analyses); $t$ stands for time (we identify the month of interview); and $p$ stands for province. The model includes, depending on the outcome, a vector of worker or household-specific characteristics $\left(X_{i t}\right)$ that control for observable compositional changes in the labor market. Explanatory variables in vector $X_{i t}$ change with the specification, but in general include individual specific human capital (a gender dummy, a quadratic term in age, and dummies for the highest level of education obtained), a dummy for married, and a dummy for living in urban areas. When we analyze employed individuals, we further include industry and occupation categories and dummy variables for firm size.

All specifications include a full set of time $\left(\delta_{t}\right)$ and provincial dummies $\left(\gamma_{p}\right)$. After including these two sets of covariates, identification is obtained from deviations of the minimum wage within provinces over time from the average yearly minimum-wage change, which can be reasonably viewed as exogenous. As an additional check, we include in some specifications the provincial real GDP per capita, which is one of the main aspects that wage setters should have taken into account during wage negotiations according to the legislation. Reassuringly, results with and without this variable are virtually identical. Thus, in line with our previous discussion, we are reasonably confident that our results do not suffer from endogeneity bias.

\subsection{The impact of the minimum wage on average wages}

We start by assessing the effect of the minimum wage on average wages, presented in table 3. Our basic specification in column 1 includes province and monthly dummies, as well as education, occupation, industry, and establishment-size dummies. In column 2 we extend this specification to control for provincial per capita GDP. The estimated elasticity of wages to the minimum wage is virtually identical in the two specifications, the point estimate being 0.36 and highly significant at the 0.1 percent level. Hence, the regression analysis confirms what previous summary statistics and visual inspection suggested: in spite of substantial noncompliance, the minimum wage in Thailand is binding, and it has a bearing on actual wages. 
Table 3. Effect of Thai Minimum Wage on Average Wages (OLS Estimates)

\begin{tabular}{lcc}
\hline \hline & $(1)$ & $(2)$ \\
\hline $\begin{array}{l}\text { Log real daily } \\
\text { minimum wage }\end{array}$ & $0.3555^{* * *}$ & $0.3623^{* * *}$ \\
$\begin{array}{l}\text { Province } \\
\text { dummies }\end{array}$ & Yes & Yes \\
$\begin{array}{l}\text { Monthly } \\
\text { dummies }\end{array}$ & Yes & Yes \\
$\begin{array}{l}\text { Individual } \\
\text { controls }\end{array}$ & Yes & Yes \\
$\begin{array}{l}\text { Education } \\
\text { Occupation }\end{array}$ & Yes & Yes \\
$\begin{array}{l}\text { Industry } \\
\text { Establishment } \\
\text { size }\end{array}$ & Yes & Yes \\
$\begin{array}{l}\text { Log real yearly } \\
\text { province per } \\
\text { capita GDP }\end{array}$ & No & Yes \\
\hline$N$ & & Yes \\
\hline \hline
\end{tabular}

Note: The dependent variable (individual daily real wages) is measured in logs. Individual controls include a male dummy, age, age squared/100, married, and municipal area indicators. Sampling weights are used, and standard errors, displayed in round brackets, are clustered. Analyses are based on working-age (15-60 years old), full-time (35+ hours per week), private sector employees.

${ }^{*} p<0.05 \quad{ }^{* *} p<0.01 \quad{ }^{* * *} p<0.001$

Table 4 moves to the analysis of the heterogeneous impact of the minimum wage on wages of different labor market groups. To simplify the exposition, we report only our preferred specification, which adds the log of real per capita GDP per province and year to the standard set of covariates. We start the analysis by examining differences across gender (in panel 1 of table 4), and our results indicate that the impact of the minimum wage is larger for females than for males. In spite of the higher level of minimum-wage noncompliance across females that we described in the previous section, the estimated elasticity of female wages almost doubles that of males (0.49 against 0.26$)$.

In panel 2 of table 4, we show the differential impact of the minimum wage across age categories. Not surprisingly, the wages of young workers (15-24 years old) are more affected than the wages of primeaged employees (25-49 years old), with estimated elasticities of 0.52 and 0.33 , respectively. These results suggest that the minimum wage has a stronger impact on the wages of low-earning workers. Perhaps more 
surprising is the finding that the minimum wage has no impact on the wages of elderly workers (50-60 years old), for whom the estimated elasticity is negative although not statistically significant.

Table 4: Effect of Thai Minimum Wage on Average Wages, by Socioeconomic Group (OLS Estimates)

\begin{tabular}{|c|c|c|}
\hline & Elasticities and standard errors & Sample size \\
\hline \multicolumn{3}{|l|}{ (1) By gender } \\
\hline Men & $\begin{array}{l}0.2640^{* * *} \\
(0.06412)\end{array}$ & 580470 \\
\hline Women & $\begin{array}{c}0.4894^{* * *} \\
(0.1060)\end{array}$ & 488664 \\
\hline \multicolumn{3}{|l|}{ (2) By age group } \\
\hline $15-23$ years & $\begin{array}{c}0.5162^{* * *} \\
(0.1144)\end{array}$ & 170691 \\
\hline 24-49 years & $\begin{array}{c}0.3318^{* * *} \\
(0.08255)\end{array}$ & 803033 \\
\hline $50-60$ years & $\begin{array}{l}-0.1740 \\
(0.1023) \\
\end{array}$ & 95410 \\
\hline \multicolumn{3}{|l|}{ (3) By education } \\
\hline Less than elementary & $\begin{array}{c}0.2835^{* * *} \\
(0.06179)\end{array}$ & 277569 \\
\hline Elementary & $\begin{array}{c}0.4043^{* * *} \\
(0.08313)\end{array}$ & 247075 \\
\hline Lower secondary & $\begin{array}{l}0.3678^{* *} \\
(0.1254)\end{array}$ & 190983 \\
\hline Upper secondary & $\begin{array}{c}0.3818^{* * *} \\
(0.1060)\end{array}$ & 171032 \\
\hline Tertiary & $\begin{array}{l}0.3455^{* * *} \\
(0.08737)\end{array}$ & 182475 \\
\hline
\end{tabular}

Note: Both the dependent variable (individual daily real wages) and the real daily minimum wage are measured in logs. Control variables in all panels include province and year-month dummies, age, age $2 / 100$, married, and municipal area dummies, occupation, establishment size, and industry indicators as well as the log of real per capita GDP per province and year. Estimations by gender (panel 1) also include education indicators, while estimations by age group (panel 2) include a male dummy as well as education indicators, and estimations by education (panel 3) also include a male dummy. Sampling weights are used and standard errors, displayed in round brackets, are clustered. Analyses based on working-age (15-60 years old), full-time (35+ hours per week) private employees.

${ }^{*} p<0.05 \quad{ }^{* *} p<0.01 \quad{ }^{* * *} p<0.001$

Panel 3 of table 4 shows differences across five educational groups: less than elementary, elementary, lower secondary, upper secondary, and tertiary. Differences in the impact of the minimum wage on daily wages 
across educational groups are in general small, with workers at the extremes of the skill distribution experiencing somewhat smaller gains than workers in the middle. The largest estimated elasticity observed is that of workers with elementary education (0.40), against an estimated elasticity of 0.28 for the group of workers who did not complete elementary education.

\subsection{Minimum wages, informality, and the intensive and extensive employment margins}

Our previous analyses confirmed that the minimum wage in Thailand is binding and showed that it shapes the wage distribution with differential impacts across different categories of workers. We estimate now the impact of the minimum wage on employment levels and the type of employment. Most of the literature has focused on the unemployment impact of the minimum wage. In the case of Thailand, however, unemployment is extremely low_-an average of 1.2 percent during the period we are analyzing — suggesting that the effect of the minimum wage, if any, should be marginal. However, the minimum wage might discourage job searching altogether, affecting the rate of joblessness rather than unemployment. Moreover, such a low unemployment rate might hide some misclassification between unemployed and nonactive individuals. For this reason, we analyze the impact of the minimum wage on the rate of employment at the provincial level.

Table 5 shows the impact of the minimum wage on the probability of working. The analysis is carried out using a logit model, where the dependent variable takes the value one if the individual is working and zero otherwise. Average partial effects are reported. Our sample consists of working-age (15-60 years old) individuals, and, as before, the estimated models control for province and year-month dummies, a quadratic term in age, gender and marital status dummies, and municipal area dummies as well as the log of real per capita GDP per province and year.

The overall estimated effect (panel 1 of table 5) of the log of the minimum wage on the probability of working is negative (-0.055) and statistically significant at the 5 percent level. Since the minimum wage is in logs, this average partial effect implies that the probability of working declines by 0.5 percentage points if the minimum wage increases by 10 percent. Considering that the average employment rate in Thailand is 77.3 percent during the estimation period, this translates into a 0.64 percent reduction of the probability of being employed. Our subsequent disaggregated analyses reveal that this figure masks important differences by gender, because it is the impact of the minimum wage on female employment that drives the average result (panel 2 of table 5). Indeed, the average partial effect for females is -0.10 and highly significant, while for males it is 0.003 and insignificant at standard levels.

Across age categories (panel 3 of table 5), the estimated effect is of similar magnitude for young and older workers, indicating about a 1 percentage point reduction in the probability of employment for each 10 percent increase in the minimum wage. However, the estimated impact is statistically significant only among 
workers aged 50 to 60 . In contrast, the effect on the employment probability for prime-aged (25-49 years old) workers is smaller in magnitude (-0.008) and not significantly different from zero.

Table 5. Effect of Thai Minimum Wage on Probability of Working (Logit Estimates)

\begin{tabular}{|c|c|c|}
\hline & APEs and standard errors & Sample size \\
\hline (1) All & $\begin{array}{l}-0.05554^{*} \\
(0.02769)\end{array}$ & 5406775 \\
\hline \multicolumn{3}{|l|}{ (2) By gender } \\
\hline Men & $\begin{array}{l}0.002783 \\
(0.02893)\end{array}$ & 2527094 \\
\hline Women & $\begin{array}{l}-0.1085^{* *} \\
(0.03454)\end{array}$ & 2879681 \\
\hline \multicolumn{3}{|l|}{ (3) By age group } \\
\hline $15-23$ years & $\begin{array}{c}-0.1129 \\
(0.08236)\end{array}$ & 983426 \\
\hline 24-49 years & $\begin{array}{c}-0.008016 \\
(0.02265)\end{array}$ & 3357350 \\
\hline $50-60$ years & $\begin{array}{l}-0.1079^{* *} \\
(0.03621)\end{array}$ & 1065999 \\
\hline \multicolumn{3}{|l|}{ (4) By education } \\
\hline Less than elementary & $\begin{array}{c}-0.1011^{* *} \\
(0.03330)\end{array}$ & 1808107 \\
\hline Elementary & $\begin{array}{l}-0.1469^{* * *} \\
(0.03812)\end{array}$ & 1027020 \\
\hline Lower secondary & $\begin{array}{c}-0.02878 \\
(0.05351)\end{array}$ & 971442 \\
\hline Upper secondary & $\begin{array}{c}0.01147 \\
(0.08135)\end{array}$ & 757715 \\
\hline Tertiary & $\begin{array}{c}0.05119 \\
(0.02986) \\
\end{array}$ & 842491 \\
\hline
\end{tabular}

Note: The dependent variable takes the value 1 if the individual is working and 0 otherwise, and the real daily minimum wage is measured in logs. Unemployed individuals are classified as nonworking. Analyses are based on working-age (1560 years old) individuals. Average partial effects (APEs) are displayed, sampling weights are used, and standard errors, displayed in round brackets, are clustered. Control variables in all panels include province and year-month dummies, age, age $^{2} / 100$, married, and municipal area dummies as well as the log of real per capita GDP per province and year. Estimations by gender (panel 2) also include education indicators, while estimations for all working-age individuals and by age group (panels 1 and 3) include a male dummy as well as education indicators, and estimations by education (panel 4) also include a male dummy.

${ }^{*} p<0.05 \quad{ }^{* *} p<0.01 \quad{ }^{* * *} p<0.001$ 
When splitting the sample into educational groups (panel 4 of table 5), the minimum wage appears to concentrate its negative impact on the less-educated employees: the probability of being employed declines by approximately 1 percentage point for each 10 percent increase in the real minimum wage for workers with less than elementary education, and this effect amounts to approximately 1.5 percentage points in the case of workers who finished elementary school. The impact for more-educated workers is always smaller in magnitude and not statistically significant.

Not surprisingly, the disemployment impact of the minimum wage disproportionally affects low-productivity employees and those workers who tend to be less attached to the labor market: female, elderly, and loweducated workers. The employment of prime-aged (25-49 years old) male workers appears instead not to be affected by minimum-wage changes. However, a second channel of selection may be at play: In the presence of binding minimum wages, some workers may be forced to move to the uncovered sector, which in Thailand and most other Southeast Asian economies is large. In particular, about 61 percent of private workers in Thailand are in the uncovered sector; that is, they are either self-employed or working in a family business for no pay. Are changes across provinces in the Thai real minimum wage associated with changes in the probability of working in the uncovered sector? Our next set of regressions investigates this question.

We estimate now the impact of the minimum wage on the probability of working in the covered or uncovered sector. To this end, we focus on private sector workers and define a dummy variable that takes the value one if the worker is an employee, and the value of zero if he or she is self-employed or an unpaid family worker. As before, our benchmark specification controls for province and year-month dummies, a quadratic term in age, married and municipal area dummies, and occupation and industry indicators as well as the log of real per capita GDP per province and year. After estimating the average partial effect on the full sample (panel 1 of table 6), we again consider worker heterogeneity by splitting the sample by gender, age, and education (panels 2-4 of table 6). In contrast with our initial expectations, our results show no signs that minimum wage increases are pushing workers into the uncovered sector in Thailand. The estimated average partial effects for all groups are always small in magnitude and never achieve statistical significance at standard levels of testing.

Another feature of Thai minimum wages that must be considered is that they are paid by the day. In an attempt to limit the impact of daily minimum-wage increases on labor costs, employers may react by adjusting working hours. The LFS asks all employed individuals the number of hours worked during the reference week, allowing us to examine the impact of the minimum wage on the intensive margin (table 7). As we did with wages, we depart from the sample of covered workers and focus on working-age (15-60 years old), full-time (35+ hours per week), private employees in their main jobs. Control variables in all panels include province and year-month dummies, a quadratic in age, married and municipal area dummies, 
establishment size, and occupation and industry indicators as well as the log of real per capita GDP per province and year.

\section{Table 6. Effect of Thai Minimum Wage on the Probability of Working in the Covered Sector (Logit Estimates)}

\begin{tabular}{|c|c|c|}
\hline & APEs and standard errors & Sample size \\
\hline (1) All & $\begin{array}{c}-0.008095 \\
(0.04377) \\
\end{array}$ & 3620959 \\
\hline \multicolumn{3}{|l|}{ (2) By gender } \\
\hline Men & $\begin{array}{c}-0.001555 \\
(0.04582)\end{array}$ & 1846136 \\
\hline Women & $\begin{array}{l}-0.02565 \\
(0.04581)\end{array}$ & 1774823 \\
\hline \multicolumn{3}{|l|}{ (3) By age group } \\
\hline $15-23$ years & $\begin{array}{c}0.01952 \\
(0.05636)\end{array}$ & 376462 \\
\hline 24-49 years & $\begin{array}{l}0.007779 \\
(0.04386)\end{array}$ & 2531539 \\
\hline $50-60$ years & $\begin{array}{l}-0.03457 \\
(0.03622)\end{array}$ & 712958 \\
\hline \multicolumn{3}{|l|}{ (4) By education } \\
\hline Less than elementary & $\begin{array}{l}-0.01285 \\
(0.05204)\end{array}$ & 1429761 \\
\hline Elementary & $\begin{array}{r}-0.05349 \\
(0.05717)\end{array}$ & 798673 \\
\hline Lower secondary & $\begin{array}{l}-0.03771 \\
(0.07756)\end{array}$ & 537740 \\
\hline Upper secondary & $\begin{array}{l}-0.05844 \\
(0.06153)\end{array}$ & 451126 \\
\hline Tertiary & $\begin{array}{l}0.008622 \\
(0.04425)\end{array}$ & 403659 \\
\hline
\end{tabular}

Note: The dependent variable takes the value 1 if the individual is working in the covered sector (that is, if he or she is a salaried employee in the private sector) and 0 is he or she is self-employed or an unpaid family worker. The real daily minimum wage is measured in logs. Analyses are based on 15- to 60-year-old individuals working in the private sector (public employees and unemployed individuals are therefore excluded from the sample). Average partial effects (APEs) are displayed, sampling weights are used, and standard errors, displayed in round brackets, are clustered. Control variables in all panels include province and year-month dummies, age, age ${ }^{2} / 100$, married and municipal area dummies, and occupation and industry indicators as well as the log of real per capita GDP per province and year. Estimations by gender (panel 2) also include education indicators, while estimations for all working-age individuals and by age group (panels 1 and 3) include a male dummy as well as education indicators, and estimations by education (panel 4) also include a male dummy.

${ }^{*} p<0.05 \quad{ }^{* *} p<0.01 \quad{ }^{* * *} p<0.001$ 
The impact of the real minimum wage on weekly working hours is positive and statistically significant at the 5 percent level, although fairly small in magnitude (panel 1 of table 7). Overall, a 10 percent rise in the minimum wage increases work hours by about 0.5 additional hours per week. Interestingly, this effect is entirely due to working-hour increases for men, particularly prime-aged men (panels 2 and 3 of table 7). When we split the sample into educational categories, the effect is largest in magnitude and statistically significant for workers with upper secondary education, although it is positive (but not statistically significant) for all educational groups.

Table 7. Effect of Thai Minimum Wage on Hours Worked per Week

\begin{tabular}{lcc}
\hline \hline & Coefficient estimates and standard errors & Sample size \\
\hline (1) All & $4.9863^{*}$ & 1211185 \\
& $(2.0830)$ & \\
\hline (2) By gender & $6.3375^{* * *}$ & 651361 \\
Men & $(1.3672)$ & 559824 \\
Women & 3.2758 & \\
& $(3.2332)$ & 187850 \\
\hline (3) By age group & & \\
15-23 years & 4.3352 & 907855 \\
24-49 years & $(2.9534)$ & 115480 \\
& $5.3258^{*}$ & \\
50-60 years & $(2.1867)$ & 335329 \\
& 2.8721 & \\
(4) By education & $(1.7268)$ & 290015 \\
Less than elementary & & 210000 \\
Elementary & 1.9850 & \\
& $(2.4561)$ & 182544 \\
Lower secondary & 3.4470 & 193297 \\
Upper secondary & $(2.4920)$ & \\
Tertiary & 5.8191 & \\
& $(3.0059)$ & \\
\hline \hline
\end{tabular}

Note: The dependent variable measures the number of hours worked per week by full-time $(35+$ hours) private employees in their main jobs, and the real daily minimum wage is measured in logs. Analyses are based on workingage (15-60 years old) individuals. Sampling weights are used, and standard errors, displayed in round brackets, are clustered. Control variables in all panels include province and year-month dummies, age, age $2 / 100$, married and municipal area dummies, establishment size, and occupation and industry indicators as well as the log of real per capita GDP per province and year. Estimations by gender (panel 2) also include education indicators, while estimations for all workingage individuals and by age group (panels 1 and 3 ) include a male dummy as well as education indicators, and estimations by education (panel 4) also include a male dummy.

${ }^{*} p<0.05 \quad{ }^{* *} p<0.01 \quad{ }^{* * *} p<0.001$ 


\subsection{Minimum wages, poverty, and household consumption inequality}

So far we have learned that Thai minimum-wages have a positive impact on the average wages of covered employees, and the effect appears to be fairly homogeneous across skill categories. If anything, the effect is smaller among the less-educated workers. Even workers with tertiary education benefit from changes in the minimum wage, which appears to signify that minimum wages represent a social norm that sets the stage for wage negotiations, even among workers who earn wages well above the minimum.

When we moved to the different margins of adjustments used by employers in response to changes in the minimum wage, we learned that, in spite of higher levels of noncompliance, the largest disemployment effects are concentrated among female, older, and less-educated workers. As expected, we found no effects on employment among workers with tertiary education. The above findings raise the question how minimumwage increases affect those who are less well-off. Ultimately, it is an empirical question whether the positive impact of the minimum wage on average wages is sufficient to compensate for its disemployment effects on the most vulnerable segments of the labor force.

In this subsection, we address this question from two different angles: the minimum wage's impact on the probability of being poor and its impact on household per capita consumption. To these purposes we rely on a new data set, the Thai Household Socio-Economic Surveys (SES), which was collected in the following years: 2000, 2002, 2004, 2006, 2007, 2008, 2009, and 2010. The incidence of poverty is obtained using a consumption approach, and follows official definitions. As such, poor households are those that are not able to fulfill minimum calorie requirements for their members. Adjustments are made to take into account the gender and age composition of the household and differences in food prices across regions (see Jitsuchon, Kakwani, and Plangpraphan, 2006). The average poverty line in 2002 was 1,190 Baht per person per month (27 US\$ of 2002), leaving some $15 \%$ of the Thai population in poverty at the time. It is worth stressing that the official poverty line has been constructed using a base year of 2002 (that is, after the 1997 economic crisis, which led to relevant changes in consumption patterns).

Table 8 presents logit estimates of the probability of the household being poor as a function of the minimum wage in the province where the household resides. In column 1 we control only for province and month-year fixed effects. Column 2 adds the household head's characteristics (a male dummy, age and its squared term, a married dummy, education, and labor market status indicators); household-level information (a municipal area dummy, household size, and indicators for the presence of household members younger than 15 and older than 59 years old); and the log of real per capita GDP per province and year. In both specifications, the estimated average partial effects are negative and fairly large: a 10 percent increase in the minimum wage is associated with a 0.7 percentage point reduction in the probability of a household being 
poor (column 2 of table 8). However, average partial effects are estimated with considerable uncertainty, and we cannot reject the null that they are equal to zero.

\section{Table 8. Effect of Thai Minimum Wage on Probability of Household Poverty (Logit APEs)}

\begin{tabular}{lll}
\hline \hline & \multicolumn{1}{c}{$(1)$} & \multicolumn{1}{c}{$(2)$} \\
\hline Log real daily minimum wage & -0.1161 & -0.07219 \\
& $(0.1203)$ & $(0.1199)$ \\
\hline Province dummies & Yes & Yes \\
Monthly dummies & Yes & Yes \\
Household head's characteristics & No & Yes \\
Household characteristics & No & Yes \\
Log real yearly province per capita GDP & No & Yes \\
\hline$N$ & 312985 & 312872 \\
\hline \hline
\end{tabular}

Note: The dependent variable takes the value 1 for poor households and 0 otherwise, and the real daily minimum wage is measured in logs. Average partial effects (APEs) are displayed, sampling weights are used, and standard errors, displayed in round brackets, are clustered. Specification 1 includes only province and year-month dummies. Specification 2 adds the household head's characteristics (male dummy, age, age $2 / 10$, married dummy, education, and labor market status indicators); household information (municipal area dummy, household size, and indicators for the presence of household members younger than 15 and older than 59 years old); and the log of real per capita GDP per province and year.

${ }^{*} p<0.05 \quad{ }^{* *} p<0.01 \quad{ }^{* * *} p<0.001$

To gain a better understanding of the impact of the minimum wage on the welfare of the poor, we now focus on the responses to minimum-wage changes of household consumption per capita. In developed countries, income per capita at the household level is commonly used as a measure of welfare. In developing countries, consumption per capita is commonly believed to be a better measure to approximate the 
permanent income of the household. Income in household surveys tends to be severely understated, a problem that is much less common in the case of consumption. ${ }^{21}$

Table 9. Effect of Thai Minimum Wage on Real Per Capita Consumption of Poor Households (OLS Estimates)

\begin{tabular}{lll}
\hline \hline & $(1)$ & $(2)$ \\
\hline Log real daily minimum wage & $0.5882^{*}$ & 0.4333 \\
& $(0.2347)$ & $(0.2233)$ \\
\hline Province dummies & Yes & Yes \\
Monthly dummies & Yes & Yes \\
Household head's characteristics & No & Yes \\
Household characteristics & No & Yes \\
Log real yearly province per capita GDP & No & Yes \\
\hline$N$ & 24008 & 24008 \\
\hline \hline
\end{tabular}

Note: Analyses are based on the sample of poor households. The dependent variable measures the real per capita consumption of poor households in logs. The real daily minimum wage is measured in logs, too. Sampling weights are used, and standard errors, displayed in round brackets, are clustered. Specification 1 includes only province and yearmonth dummies. Specification 2 adds the household head's characteristics (male dummy, age, age $2 / 10$, married dummy, education, and labor market status indicators); household information (municipal area dummy, household size, and indicators for the presence of household members younger than 15 and older than 59 years old); and the log of real per capita GDP per province and year.

${ }^{*} p<0.05 \quad{ }^{* *} p<0.01 \quad{ }^{* * *} p<0.001$

In table 9, we restrict the analysis to poor households and estimate the response of their per capita consumption to changes in the minimum wage. The dependent variable measures (in logs) the real per capita consumption of poor households, and the regressors are the same as in the previous poverty analyses. The specification in column 1 of table 8, which controls only for province and month-year fixed effects, indicates

${ }^{21}$ We do not use equivalence scales to adjust household consumption per capita levels. We prefer instead to control for the number of children and elder dependents in the household to account for potential economies of scale. 
that the impact of the minimum wage on per capita household consumption is positive and statistically significant at the 5 percent level. Moreover, the estimated elasticity is fairly large: a 10 percent increase in the minimum wage is associated with an increase in consumption per capita of almost 6 percent for poor households. However, adding household controls to the regression (column 2 of table 9) reduces the estimated elasticity to 0.4 , which becomes significant only at the 10 percent level.

Finally, we focus on the distributional effects of the minimum wage. In particular, we look into the effect of the minimum wage along the per capita household consumption distribution. While LFS wage data are available only for employees, per capita household consumption is available for all households in the SES, which allows us to provide a broader picture of the welfare effects of minimum-wage legislation. The use of consumption per capita data has some advantages over alternative summary measures of well-being such as income. Consumption data are expected to be smoother and less prone to underreporting than income data. Moreover, consumption captures household welfare better than income, as utility depends on consumption. Even if household consumption may not be a perfect proxy for welfare (especially among high-earning households with some saving capacity), the analysis has the potential of capturing some of the general equilibrium effects of the minimum wage.

The analysis is conducted using standard quantile regressions. The dependent variable is the log of per capita real household consumption, and explanatory variables are the (log of) the real daily minimum wage; household heads' characteristics (male and married dummy, age and its quadratic term, education, and labor market status indicators); a municipal area; indicators of household composition (household size and indicators for the presence of household members younger than 15 and older than 59 years old); and the log of real per capita GDP per province and year. Figure 4 reports the results. Interestingly, the minimum wage has a positive impact on per capita household consumption that is statistically significant at all percentiles below the 90th. However, this effect is not uniform along the distribution, presenting an inverted U-shape. In particular, the estimated elasticity reaches its maximum (0.35) at the 65th percentile, almost doubling the elasticities estimated at the lower percentiles of the distribution and more than doubling those estimated beyond the 90 th percentile. 
Figure 4: Impact of Thai Minimum Wage along Distribution of Real Per Capita Household Consumption

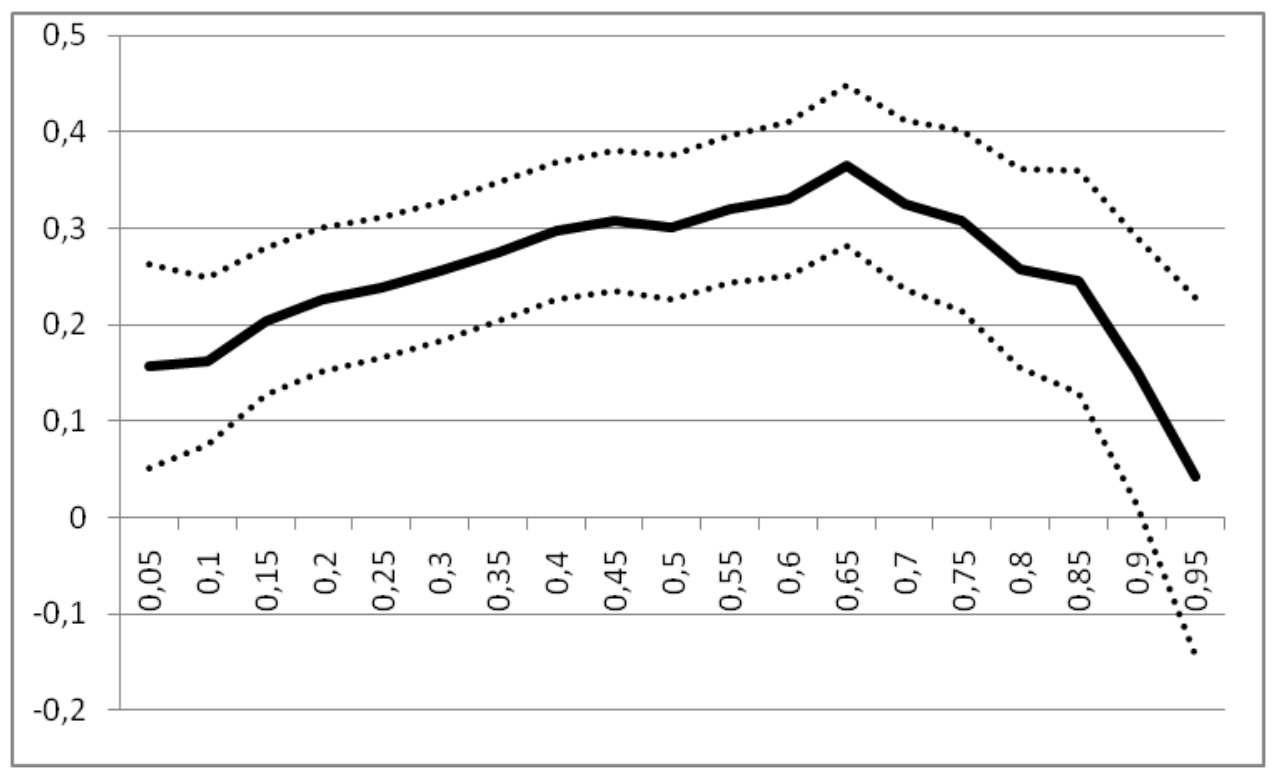

Note: Quantile regression estimates (solid lines) and their associated confidence intervals (dotted lines) are plotted. The dependent variable (per capita real household consumption.) is measured in logs, and so is the real daily minimum wage. Control variables include household heads' characteristics (male dummy, age, age $2 / 10$, married dummy, education, and labor market status indicators); a municipal area dummy; information on household composition (size and indicators for the presence of household members younger than 15 and older than 59 years old); and the log of real per capita GDP per province and year. 


\section{Concluding Remarks}

The minimum wage in developing countries is often seen as a fundamental tool for lifting the labor market fortunes of the less favored. However, such a tool may not be effective for several reasons: To begin with, it is well known that the minimum wage may have adverse effects on employment, precisely among those workers who are less productive, such as the young, the elderly, and the less-educated in general. Moreover, these effects may be exacerbated in developing countries, where large fractions of the labor force are employed through informal arrangements and hence not covered by minimum-wage laws. Even among formally registered firms, among which one would expect greater enforcement, minimum-wage laws are associated with considerably high levels of noncompliance. Hence, it is in principle unclear whether the minimum wage constitutes the right tool for reducing inequality and, ultimately, for alleviating poverty.

This paper examined the impact of the minimum wage on key labor market variables including employment and wages, but it also extended the analysis to study the impact on household poverty and consumption per capita during the past decade in Thailand. We find that minimum wage increases also increase actual wages generally, and they do so more for female and young workers than for prime-aged male employees. The estimated elasticities are in the range of $0.25-0.5$, depending on the subgroup analyzed, and the average elasticity for the general population of full-time formal sector employees is 0.36 . Importantly, we do not find evidence of minimum wage increases pushing workers into the uncovered sector (comprising self-employed and unpaid family workers). However, some negative effects of the minimum wage are also detected: it reduces the probability of being employed, especially among women and elderly workers, although the estimated impacts are small.

At the aggregate level, the positive impact of the minimum wage on actual wages more than compensates for the negative effects on employment. Back-of-the-envelope calculations suggest that, even evaluating employment losses as zero wages, a 10 percent rise in the real minimum wage would have resulted in an increase of 2.6 percent in the wage bill. However, these gains are not uniformly distributed across the population: medium- and high-skilled workers benefit the most from a minimum-wage increase.

This conclusion is confirmed by our analysis of the impact of the minimum-wage increases on consumption per capita at the household level. Although such an impact is always positive-suggesting that consumption increased more in those provinces where minimum wages grew faster-the largest gains from minimum-wage rises are observed around the 6th decile of the consumption per capita distribution. In fact, the minimum wage increased inequality at the bottom half of the distribution, and our estimates are inconclusive about the scope of minimum wages for poverty reduction in Thailand. 


\section{References}

Alatas, Vivi and Lisa Cameron. 2008. "The Impact of Minimum wages on Employment in a Low Income Country: A Quasi-Natural Experiment in Indonesia”, Industrial and Labor Relations Review, Vol. 61, No. 2, pp. 201-223

Bell, Linda 1997. "The Impact of Minimum Wages in Mexico and Colombia." Journal of Labor Economics 15 (3): S102-S134.

Card, David, and Alan B Krueger. 1997. "Myth and measurement: The new economics of the minimum wage". Princeton, NJ: Princeton University Press.

Chandoevwit, Worawan 2010. "The Impact of the Global Financial Crisis and Policy Responses in Thailand." TDRI Quarterly Review 25 (1): 12-24.

Margherita Comola \& Luiz De Mello, 2011. "How Does Decentralized Minimum Wage Setting Affect Employment And Informality? The Case Of Indonesia," Review of Income and Wealth, International Association for Research in Income and Wealth, vol. 57, pages S79-S99, 05.

Cunningham, Wendy V. 2007. "Minimum Wages and Social Policy: Lessons from Developing Countries". Directions in Development Series. Washington, DC: World Bank.

Del Carpio, Ximena, Ha Nguyen, and Liang Choon Wang. 2011. "Does the Minimum Wage Affect Employment? Evidence from the Manufacturing Sector in Indonesia". World Bank Policy Research Working Paper 6147

DLPW (Department of Labour Protection and Welfare). 2002. Report of a Study on Wages, Earning, and Hours of Work [in Thai]. Bangkok: Report of the Ministry of Labour.

Dickens, Richard, Stephen Machin, and Alan Manning. 1999. "The Effects of Minimum Wages on Employment: Theory and Evidence from Britain.” Journal of Labor Economics 17 (1): 1-22.

Flinn, Christopher 2010. “The Minimum Wage and Labor Market Outcomes”. Cambridge, MA: MIT Press.

Gindling, T. H., and Katherine Terrell. 2007. "The Effects of Multiple Minimum Wages throughout the Labor Market: The Case of Costa Rica." Labour Economics 14 (3): 485-511.

- 2009. "Minimum Wages, Wages and Employment in Various Sectors in Honduras." Labour Economics 16 (3): 291-303.

ILO (International Labour Office). 2010. Global Wage Report 2010/11: Wage Policies in Times of Crisis. Geneva: ILO.

Jitsuchon, S., N. Kakwani, and J. Plangpraphan. 2006. “Thailand's New Official Poverty Line.” Paper submitted to the National Economic and Social Development Board of Thailand and the United National Development Programs. Bangkok.

Leckcivilize, Attakrit. 2013. "Minimum Wage and Wage Inequality in Thailand: A Failed Instrument?"Unpublished manuscript, London School of Economics 
Lemos, Sara. 2009. "Minimum Wage Effects in a Developing Country.” Labour Economics 16 (2): 224-37.

Magruder, Jeremy. 2013. “Can Minimum Wages Cause the Big Push? Evidence from Indonesia.” Journal of Development Economics 100 (1): 48-62.

Maloney, William, and Jairo Núñez. 2003. "Measuring the Impact of Minimum Wages: Evidence from Latin America." In Law and Employment: Lessons from Latin America and the Caribbean, edited by J. Heckman and C. Pagés, 109-30. Chicago: University of Chicago Press.

Neumark, David and William Wascher . 2008 Minimum Wages. Cambridge: MIT Press

New York Times. 2013. “Obama’s 2013 State of the Union Address.” Speech transcript. February 12.

Nguyen Viet, Cuong. 2010. "The Impact of a Minimum Wage Increase on Employment, Wages and Expenditures of Low-Wage Workers in Vietnam.” MPRA Paper No. 36751

NSO (National Statistical Office of Thailand). 2011. "Informal Employed Persons Survey 2011.” Annual report of survey data, NSO, Bangkok.

Paitoonpong, S., N. Akkarakul, and C. Sukaruji. 2005. “The Minimum Wage-Fixing System in Thailand.” TDRI Quarterly Review 20 (2): 3-11.

Peetz, David. 1996. Review of Minimum Wage Fixation in Thailand. Bangkok: ILO East Asia Multidisciplinary Advisory Team.

Rama, Martin. 2001. “The Consequences of Doubling the Minimum Wage: The Case of Indonesia.” Industrial and Labor Relations Review 54 (4): 864-81.

Terrell, Katherine, Almeida, Rita K.. 2008. "Minimum Wages in Developing Countries : Helping or Hurting Workers?”. https://openknowledge.worldbank.org/handle/10986/11742 License: CC BY 3.0 Unported." World Bank, Washington, DC. 